\title{
Two new endangered species of Polygala series Trichospermae (Polygalaceae), endemic to the Cerrado domain, Tocantins State, Brazil
}

\author{
José Floriano Barêa PASTORE ${ }^{1, *}$ \& Guilherme Medeiros ANTAR ${ }^{2}$ \\ ${ }^{1}$ CTBS Herbarium. Universidade Federal de Santa Catarina, Campus Curitibanos, Rodovia Ulisses \\ Gaboardi, km 3, Curitibanos, 89520-000, Santa Catarina, Brazil. \\ ${ }^{2}$ Universidade de São Paulo, Instituto de Biociências, Departamento de Botânica, Rua do Matão 277, \\ 05508-090, São Paulo, SP, Brazil. \\ ${ }^{2}$ Instituto Tecnológico Vale, Rua Boaventura da Silva, 955, Belém, PA 66055-090, Brazil. \\ *Corresponding author: jfpastore@hotmail.com \\ ${ }^{2}$ Email: guilherme.antar@gmail.com \\ $1 \odot$ https://orcid.org/0000-0003-4134-7345 \\ $2 \odot \mathrm{https} / / /$ orcid.org/0000-0001-8109-4544
}

\begin{abstract}
The Cerrado domain is the most diverse savannah biome in the world and a biodiversity hotspot for conservation. Only a few areas of the domain remain well preserved, among them the Jalapão region in Tocantins State, currently is considered the best preserved area of the Brazilian Cerrado. Listed in a recent Angiosperm checklist for the region, there were two species of Polygala series Trichospermae, which were recognized as new by the first author. Polygala bringelii sp. nov., endemic to the Jalapão region, is diagnosed by its obclavate seeds without a ring of trichomes at their base, keel with the crest shorter than the cuculus, and the internal sepals (wings) longer than the capsule. Polygala tocantinensis sp. nov., endemic to Tocantins state, is distinguished by its internal sepals (wings) with two glands near to the rounded apex, and a ring of convergent trichomes at the base of the seeds. The two species are morphologically closest with Polygala trichosperma of sect. Timutua, series Trichospermae, but differs in its corolla and seeds shape and pubescence. An identification key, photographic plates, photos of floral parts under magnification, preliminary conservation assessments, and ecological comments of both species are also provided.
\end{abstract}

Keywords. Brazilian savannah, Cerrado, endangered species, Fabales, Polygala sect. Timutua, series Trichospermae.

Pastore J.F.B. \& Antar G.M. 2021. Two new endangered species of Polygala series Trichospermae (Polygalaceae), endemic to the Cerrado domain, Tocantins State, Brazil. European Journal of Taxonomy 762: 133-148. https://doi.org/10.5852/ejt.2021.762.1459 


\section{Introduction}

The Cerrado domain with an original area of approximately 2 million square kilometers is predominantly located in central Brazil with smaller areas in Bolivia and Paraguay (Ratter et al. 1997). It is regarded as the most diverse savannah biome in the world (Forzza et al. 2012), with over 12800 land plant species recognized for Brazil, of which more than 5,100 are endemic (Flora do Brasil 2020). Despite its high diversity and biomass values, this region is threatened by habitat loss, fragmentation, biological invasion and climate change (Ratter et al. 1997; Klink \& Machado 2005; Strassburg et al. 2017). Nevertheless, the domain has received less conservationism attention if compared to the neighboring domains Atlantic Forest and Amazon Forest (Strassburg et al. 2017). Mostly due to the expansion of agriculture, ca $50 \%$ of the original area of the Cerrado has been profoundly altered (Beuchle et al. 2015), with only a few areas currently under protection (Strassburg et al. 2017), making it a hotspot for conservation (Mittermeier et al. 2011). Among the few large areas of the Cerrado still in a good preservation status is the Jalapão region of Tocantins State, in the border area between the states of Bahia, Maranhão, and Piauí, the largest preserved Cerrado area (Schmidt et al. 2007; Antar \& Sano 2019).

The largest continuous protected area of the Cerrado (Silva \& Bates 2002), the Jalapão region, includes 10 protected areas, of which the Parque Estadual do Jalapão, Estação Ecológica Serra Geral do Tocantins, and Parque Nacional Nascentes do Parnaíba (Schmidt et al. 2007; Antar \& Sano 2019) stand out. A recent checklist of its grassland and savannah biomes on dry non-rocky soils (Antar \& Sano 2019) recognized 550 species and estimated that the complete flora may include over 1,000 species. Polygala was one of the richest genera recorded, with 10 species, seven of them from Polygala series Trichospermae. Among these, two new taxa were recorded, one of them being a new endemic species previously recognized by JFBP and the other was named at the time Polygala aff. trichosperma Jacq., but upon examination was recognized as a distinct new species, collected also in the municipality of Dianópolis, near the Jalapão region.

Polygala L. (Polygalaceae), with ca 580 species (ca 285 in the Neotropics), is the most speciose genus of the family (Pastore 2018a). The genus is found mostly in savannah and grassland biomes, and is characterized by the habit of herbs or subshrubs, the calyx persistent in fruit, or, if deciduous, then the keel with a crest. It is represented in Brazil by 108 species, found in all of its domains, but mainly in the Cerrado (Flora do Brasil 2020). Polygala sect. Timutua, series Trichospermae s. lat. (including ser. Ericoideae Marques), with 32 species, is almost exclusive to Brazil, but also has some putative species endemic to Venezuela and Mexico (Pastore et al. 2019). The series is monophyletic and is characterized by slender annuals with alternate leaves (the lowest sometimes whorled or opposite), short racemes, small yellow glands on the floral parts (mainly in the capsule), relatively long flowers, style often elongated and seeds oval, sub-oblong, obclavate, or conic, glabrous or pilose, eventually with ring of trichomes at base (Blake 1916; Pastore et al. 2019). Collecting efforts and taxonomic studies over the last decade have resulted in the discovery of several new species of Polygala (e.g., Pastore 2013, 2016a, 2016b, 2018a, 2018b). Two of them, from Polygala ser. Trichospermae, endemic to Tocantins state, Brazil, are here described. We also provide an identification key, photographic plates, photos of floral parts under magnification, preliminary conservation assessments, as well as taxonomic and ecological comments for both species.

\section{Material and methods}

Specimens were studied and collected in situ, following traditional techniques (Mori et al. 2011) and deposited in the SPF herbarium, with duplicates sent to the CTBS herbarium. Additional herbarium specimens from CEN, CTBS, HRCB, HTO, HUEFS, MBM, SPF, UB and UEC (herbarium acronyms after Thiers 2021) were also analyzed. A 10-60 × magnification stereomicroscope was used to analyze morphological features. The terminology to describe two-dimensional shapes followed Hickey (1973), 
general morphology followed Beentje (2012) and Harris \& Harris (2001) and family-specific terminology followed Chodat (1893) and Marques (1988).

The distribution map was produced in QGIS ver. 3.0.1 (QGIS Development Team 2020). The coordinates were obtained from the herbarium labels. When not geo-referenced, the geographic coordinates were approximated using localities mentioned on the specimen labels. Informal conservation status assessments were based on range area, criterion B of IUCN (2012), using the estimated area of occupancy (AOO) and the extent of occurrence (EOO), both simultaneously calculated using the GeoCAT tool (Bachman et al. 2011).

\title{
Results
}

\section{Taxonomic treatment}

\author{
Class Magnoliopsida Brongn. \\ Order Fabales Bromhead \\ Family Polygalaceae Hoffmannsegg \& Link \\ Genus Polygala L. \\ Subgenus Polygala subg. Polygala L. \\ Section Polygala sect. Timutua DC. \\ Series Polygala sect. Timutua ser. Trichospermae Chodat \\ Polygala bringelii J.F.B.Pastore \& Antar sp. nov. \\ urn:lsid:ipni.org:names:77219129-1
}

Figs $1-3$

\section{Diagnosis}

Polygala bringelii sp. nov. is similar to P. trichosperma Jacq. but differs from it by the obclavate seeds without a ring of trichomes at the base, keel with a crest shorter than the cuculus, and internal sepals (wings) longer than the capsule (vs conical seeds with a ring of trichomes at the base, keel with the crest and cuculus almost the same length and internal sepals shorter than or subequal the length of capsules in P. trichosperma).

\section{Etymology}

The specific epithet honors Dr João Bernardo de Azevedo Bringel Junior, a prominent Brazilian synanterologist and connoisseur of the Cerrado flora. During his career at the University of Brasília and the CENARGEN he has made numerous collecting expeditions in that domain and collected one of the paratypes of this new species.

\section{Material examined}

Type

BRAZIL - Tocantins • Mateiros, Próximo a Fazenda Lua Cheia, acessado pela antiga estrada São Felix Mateiros; 10³2'02.8" S, 46²7'43.4" W; 543 m alt.; 24 Jan. 2014; "G.M. Antar et L.F. Nascimento 380; holotype : CTBS[n. 3715], isotype : SPF[SPF00220131]".

\section{Paratypes}

BRAZIL - Tocantins • Mateiros, Parque Estadual do Jalapão, estrada de terra Mateiros-Ponte Alta do

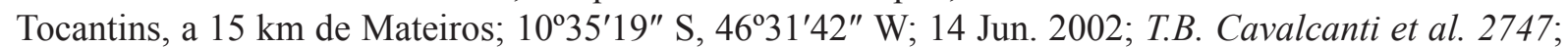
CEN[CEN00053241], CTBS[n. 341] • Parque Estadual do Jalapão, Mumbuca, brejo do Antônio, local de extração de Capim Dourado; 10²2'17" S, 46³4'58" W; 17 Jun. 2002; T.B. Cavalcanti et al. 2890; CEN[CEN00053271], CTBS[n. 335] • Área de implementação do centro de recepção de visitantes do 
PEJ; 10³4'35.6" S, 46030'25.9" W; 24 May 2003; E.R. Santos et al. 939; HTO • Parque Estadual do Jalapão, brejo dos veados, próximo a pequeno morro; 8 Aug. 2006; M. Watanabe, P.T. Sano and M.L.O. Trovó 22; CTBS[n. 3724], SPF[SPF00222919] • Jalapão, estrada para o local popularmente conhecido como Varjão; 10²4'32.3" S, 46³9'11.9" W; 430 m alt.; 6 Aug. 2013; G.M. Antar and P.T. Sano 233; SPF[SPF00220129] • Parque Estadual do Jalapão, Próximo a Fazenda Lua Cheia, acessado pela antiga estrada São Felix Mateiros; 10³2'02.8" S, 46²7'43.4" W; 543 m alt.; 20 Jan. 2014; G.M. Antar and L.F. Nascimento 346; SPF[SPF00220130] - Parque Estadual do Jalapão, margens da TO-255; 10³6'15.1" S, 46³5'43.3" W; 2 Jul. 2014; J.A. Lombardi et al. 10344; HRCB[n. 63162], UPCB • Ponte Alta do Tocantins, Cachoeira da Velha; 29 May 2008; J.M. Silva et al. 6869; CTBS[n. 2533], MBM[ n. 343560], SPF[SPF00230507] - estrada de terra de Ponte Alta do Tocantins a Mateiros, $58.6 \mathrm{~km}$ de Ponte Alta; $10^{\circ} 26^{\prime} 21^{\prime \prime} \mathrm{S}, 47^{\circ} 08^{\prime} 49^{\prime \prime} \mathrm{W} ; 27$ Mar. 2011; J.B. Bringel and H.J.C. Moreira 729; UB.

\section{Description}

Erect herbs $20-40 \mathrm{~cm}$ tall; roots rigid; single to multiple stems arising from the base, branching from the base to the apex, cylindrical, green, without yellowish glands, densely puberulous, trichomes short-clavate. Leaves all alternate, subsessile, chartaceous, laminas $(0.6-) 0.8-1 \times 0.08-0.1 \mathrm{~cm}$, linear, apex acute, margins revolute, base acute, densely covered by small glandular trichomes on both sides. Racemes congested to shortly elongated $1.2-1.9 \times 0.8-1 \mathrm{~cm}$, up to $3.3 \mathrm{~cm}$ long after capsules have fallen; bracts $1.2 \times 0.5 \mathrm{~mm}$, lanceolate, apex acute, not ciliate, without yellowish glands, deciduous before anthesis, ca 2 times as long as the bracteoles; bracteoles elliptic, not ciliate; pedicel $1.5 \mathrm{~mm}$ long, glabrous. Flowers yellow, cream or whitish, 5.4-5.5 mm long (without pedicel); outer sepals not ciliate, with yellow glands; lower outer sepals $1.5 \times 0.6 \mathrm{~mm}$, elliptic to ovate, apex obtuse; upper outer sepals $1.4-1.5 \times 0.6-0.7 \mathrm{~mm}$, elliptic, apex rounded or slightly retuse; inner sepals (wings) $4.5 \times 2.2 \mathrm{~mm}$, elliptic, apex acute, margins not ciliate, longer than the mature fruits, without yellow glands; lateral petals $4.1 \times 1 \mathrm{~mm}$; keel ca $3.5 \mathrm{~mm}$ long, cristate, with yellow glands around the dorsal central vein, deciduous on mature fruits; crest 4-6-lobed; central lobes often bi-lobed to apex, style $1.5 \mathrm{~mm}$ long, erect, terminated by an oblique cymbiform pre-stigmatic cavity, posterior extremity with a conspicuously crested appendage with abundant trichomes and an anterior globose stigma. Capsules $3.5 \times 1.7 \mathrm{~mm}$, subovate, bearing a double line of orange glands close to the central nervure, style deciduous in fruit; seeds ca $2.5 \times 1-1.1 \mathrm{~mm}$, obclavate, pubescent, trichomes $0.1-0.2 \mathrm{~mm}$ long, without a ring of trichomes at the base of the seed, with two caruncular appendages $1.5 \times 0.2-0.3 \mathrm{~mm}$ reaching approximately $1 / 2$ of the seed length.

\section{Distribution, habitat, and phenology}

Polygala bringelii sp. nov. is endemic to the Jalapão region, Tocantins State, occurring in open natural grasslands with scattered shrubs (campo sujo and campo cerrado), occasionally near rocky outcrops, on sandy dry soils at altitudes of 350 to 550 meters in the municipalities of Mateiros and Ponte Alta do Tocantins (Fig. 2). Found fertile in January and from May to August.

\section{Preliminary conservation status}

The estimated Area of Occupancy, with just $36 \mathrm{~km}^{2}$, is low; the estimated Extent of Occurrence is $1469.542 \mathrm{~km}^{2}$. The species is currently known from ten collections, with most located inside the protected area of the Parque Estadual do Jalapão. Nominally protected, these areas are still subjected to uncontrolled anthropic fires, though recently diminished in number due to a new fire management program (Schmidt et al. 2018). Nearby areas, mostly in western Bahia State, have already been converted to agricultural use (Borges \& Antar 2016), which is expanding towards the Jalapão with governmental incentives (Antar et al. 2018; Barbosa-Silva \& Antar 2020). Although still regarded as data deficient, due to the precarious state of conservation of its suitable habitats, the species should be assessed as Endangered EN B1ab(i,ii,iii)+2ab(i,ii,iii) (IUCN 2012). 


\section{Notes}

Morphologically, Polygala bringelii sp. nov. is most closely related to P. trichosperma, with both species sharing the oblong-elliptic capsules with yellow glands along the mid-vein and linear leaves. However, P. bringelii sp. nov. differs from P. trichorperma in the characters discussed in the diagnosis. Also, this new species is seemingly similar to Polygala tocantinensis sp. nov. (the other new species here described), both of them share similar sepals and yellowish flowers, differing mainly by the seed indument, with a ring of long trichomes at the seed base (vs seed without a ring of trichomes at the base in P. bringelii sp. nov.) and the keel crest in P. tocantinensis sp. nov. is much more developed (ca twice the size) than in P. bringelii sp. nov.

Polygala tocantinensis J.F.B.Pastore \& Antar sp. nov. urn:lsid:ipni.org:names:77219130-1

Figs 4-6

\section{Diagnosis}

Polygala tocantinensis sp. nov. is similar to P. trichosperma but differs from it by its internal sepals (wings) with two glands near the rounded apex, and convergent ring of trichomes at the base of the seed (vs internal sepals without glands and with acute apex, and divergent ring of trichomes at the base of the seed in P. trichosperma).

\section{Etymology}

The specific epithet is a reference to Tocantins State where the species is endemic. Two phytogeographic domains of the state, the Amazon and the Cerrado, are known for large areas of vegetation in a good conservation status. Even though new species from Tocantins are being continuously described (e.g., Araújo et al. 2016; Moreira et al. 2017; Barbosa-Silva \& Antar 2020; Silva et al. 2020), the flora of the state is relatively poorly known (BFG 2015) and more collecting efforts are in order.

\section{Material examined}

Type

BRAZIL - Tocantins • Dianópolis, Garganta, campo rupestre, 26 May 2008; fl.; J.M. Silva, J. Cordeiro and J. Vaz 6769; holotype: CTBS[n. 2532], isotype: MBM[MBM341152].

\section{Paratypes}

BRAZIL - Tocantins - Mateiros. Parque Estadual do Jalapão, Estrada entre Mateiros e povoado de Mumbuca; 10 May 2011; E. Barbosa, J. Cordeiro and J.M. Silva 3231; CTBS[n. 2553], MBM, SPF[SPF00230503] - Estrada Mateiros-São Félix do Tocantins, aproximadamente $9 \mathrm{~km}$ de Mateiros, elevação à direita da estrada; $10^{\circ} 28^{\prime} 21.8^{\prime \prime} \mathrm{S}, 4^{\circ} 27^{\prime} 14.9^{\prime \prime} \mathrm{W} ; 603 \mathrm{~m}$ alt.; 20 Sep. 2012; L.M. Borges et al. 855; SPF[SPF00211698] • Estação Ecológica Serra Geral do Tocantins, estrada central que corta a

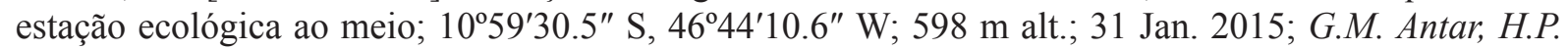
Antar and U.R. Chagas 737; SPF[SPF00220126]. 


\section{Description}

Herbs 20-50 cm tall; roots lignose, not fleshy; stems erect, branched mostly near the apex, \pm angulate, deeply costate, glabrous, green, without yellowish glands. Leaves all alternate, subsessile, chartaceous, mostly restricted to the base of stems, ocasionally nearly absent, laminas 3.2-5.2 $\times 0.4-0.6 \mathrm{~mm}$, linear, apex acute, base acute, glabrous, margins plain. Racemes congested, $0.7-1.2 \times 1-1.2 \mathrm{~cm}$, up to $2.2 \mathrm{~cm}$ long after capsules have fallen, flowers congested; bracts $0.9-1.1 \times 0.5 \mathrm{~mm}$, lanceolate, apex cute, notciliate, without glands, deciduous before anthesis, ca. 1.5 times as longer as bracteoles; bracteoles ca $0.7 \mathrm{~mm}$ long, elliptic, not ciliate; pedicel 1.2-1.6 mm long, glabrous. Flowers lilac, purple or pinkish, 4.5-5.3 mm long (without pedicel); outer sepals not ciliate, with orange glands; lower outer sepals 1.5-1.9 $\times 0.6-0.8 \mathrm{~mm}$, elliptic to ovate, apex acute; upper outer sepals 1.9-2.2 $\times 1-1.1 \mathrm{~mm}$, elliptic, with orange glands at the base, apex obtuse; inner sepals (wings) 3.9-4.6 $\times 2.3-2.7 \mathrm{~mm}$, elliptic, apex obtuse, margins not ciliate, longer than the mature fruits, with orange glands at the base and apex; lateral petals 4.1-4.2 × 0.9-1.2 mm; keel ca 3.1-3.2 mm long, cristate, with yellow glands around the dorsal central vein, deciduous on mature fruits; crest 4-6-lobed; central lobes often 2- or 3-lobed at apex; style 1.5-1.6 mm long, erect, terminated by an oblique cymbiform pre-stigmatic cavity, posterior extremity with a conspicuously crested appendage with abundant trichomes and an anterior globose stigma. Capsules 3.3-3.5 $\times 2.2-2.3 \mathrm{~mm}$, subovate, bearing a double line of orange glands (according to Fig. 4) close to the central nerve, style deciduous in fruit; seeds 2.3-2.5 $\times 0.9-1.0 \mathrm{~mm}$, subconical to obclavate, pubescent, trichomes ca $0.3 \mathrm{~mm}$ long, ring of trichomes at the base of the seed to $0.7 \mathrm{~mm}$; caruncular appendages $1.1-1.2 \times 0.1-0.2 \mathrm{~mm}$ reaching approximately $1 / 2$ the seed length.

\section{Distribution, habitat, and phenology}

Polygala tocantinensis sp. nov. grows in open natural grasslands with scattered shrubs (campo sujo), occasionally near rocky outcrops, on sandy dry soils, sometimes recently burned, at altitudes of 410 to 820 meters alt., in the Tocantins municipalities of Dianópolis and Mateiros (Fig. 5). Although considered for now endemic to Tocantins State, Polygala tocantinensis sp. nov. may also occur in the municipality of Formosa do Rio Preto, Bahia State, as the type collection was made at the division between the two states. Future collecting efforts in a similar physiognomy in Bahia State may prove successful for finding new populations of $P$. tocantinensis sp. nov.

\section{Preliminary conservation status}

The estimated Area of Occupancy, with just $16 \mathrm{~km}^{2}$, is low; the estimated Extent of Occurrence is $1831.048 \mathrm{~km}^{2}$. This species is known from only four collections in four different localities, with two of these located inside the protected areas of the Parque Estadual do Jalapão and Estação Ecológica Serra Geral do Tocantins. As is the case with Polygala bringelii sp. nov., these areas are still subjected to uncontrolled anthropogenic fires and are been rapidly converted to agricultural use. Although still regarded as data deficient, due to the precarious state of conservation of its suitable habitats, the species should be assessed as Endangered EN B1ab(i,ii,iii)+2ab(i,ii,iii) (IUCN 2012).

\section{Notes}

Morphologically, Polygala tocantinensis sp. nov. is most closely related to P. trichosperma, with both species sharing the oblong-elliptic capsules with yellow or orange glands along the mid vein and linear leaves. However, $P$. tocantinensis sp. nov. differs from $P$. trichorperma in the characters discussed in the diagnosis. This new species is also superficially similar to Polygala bringelii sp. nov. (see comments above). 




Fig. 1. Polygala bringelii J.F.B.Pastore \& Antar sp. nov. A. Flower. B. Bracteoles. C. Bract. D. Two upper outer sepals. E. Lower outer sepal. F. One of the two inner sepals (wings). G. Gynoecium. H. Crest. I. Keel. J. Androecium and lateral petals. K. Fruit with persistent calyx. L. Capsule. M. Seed. All from G.M. Antar and L. Nascimento 380. Photos: J.F.B. Pastore. 


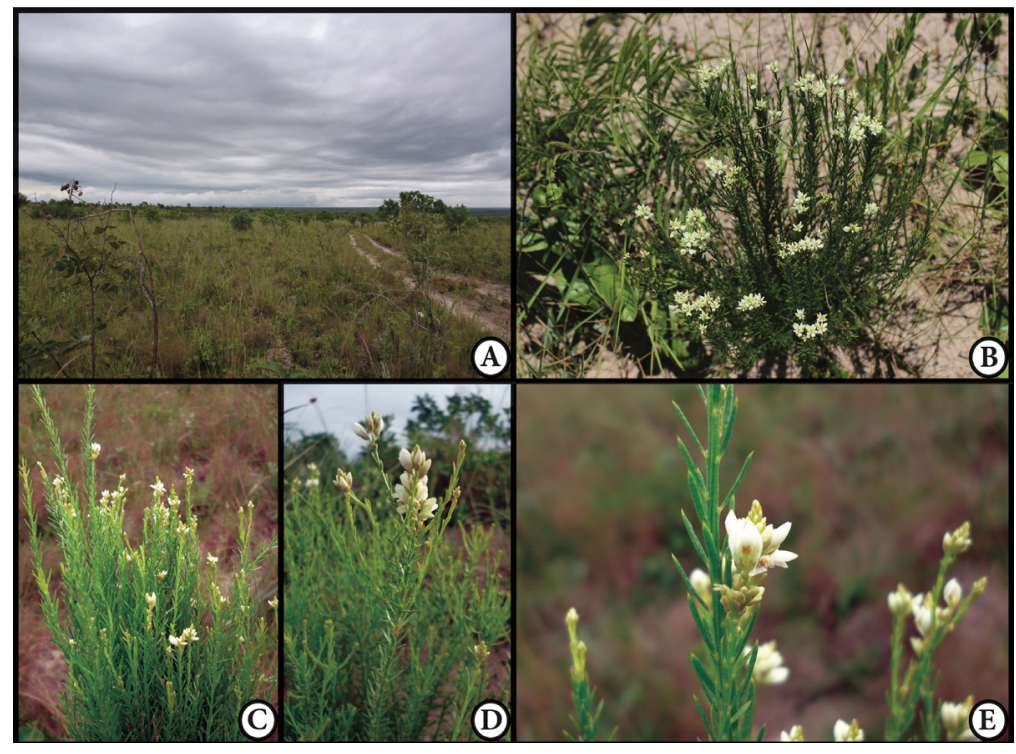

Fig. 2. Polygala bringelii J.F.B.Pastore \& Antar sp. nov. A. Habitat. B. Habit. C-D. Flowering branches. E. Inflorescence detail. Photos: G.M. Antar, in situ.

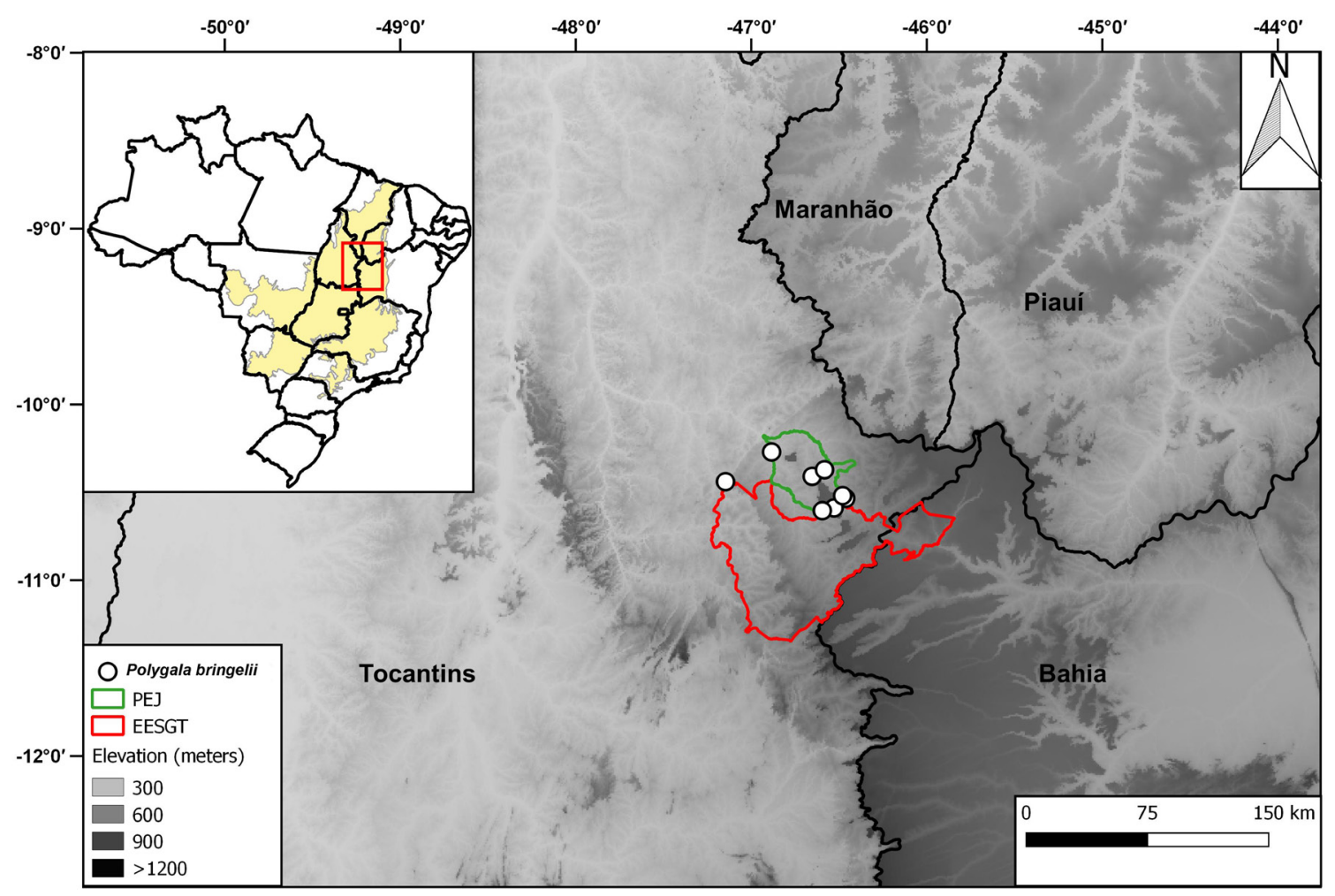

Fig. 3. Geographical distribution of Polygala bringelii J.F.B.Pastore \& Antar sp. nov. (circles). PEJ = Parque Estadual do Jalapão, EESGT = Estação Ecológica Serra Geral do Tocantins. The cream-colored portion of the insert map shows the extent of the Cerrado domain in Brazil. 




Fig. 4. Polygala tocantinensis J.F.B.Pastore \& Antar sp. nov. A. Flower. B. Bracteoles. C. Bracts. D. Two upper outer sepals. E. Lower outer sepal. F. One of the two inner sepals (wings). G. Gynoecium. H. Crest. I. Keel. J. Androecium and lateral petals. K. Fruit with persistent calyx. L. Capsule. M. Seed. All from J.M. Silva, J. Cordeiro and J. Vaz 6769. Photos: J.F.B. Pastore. 


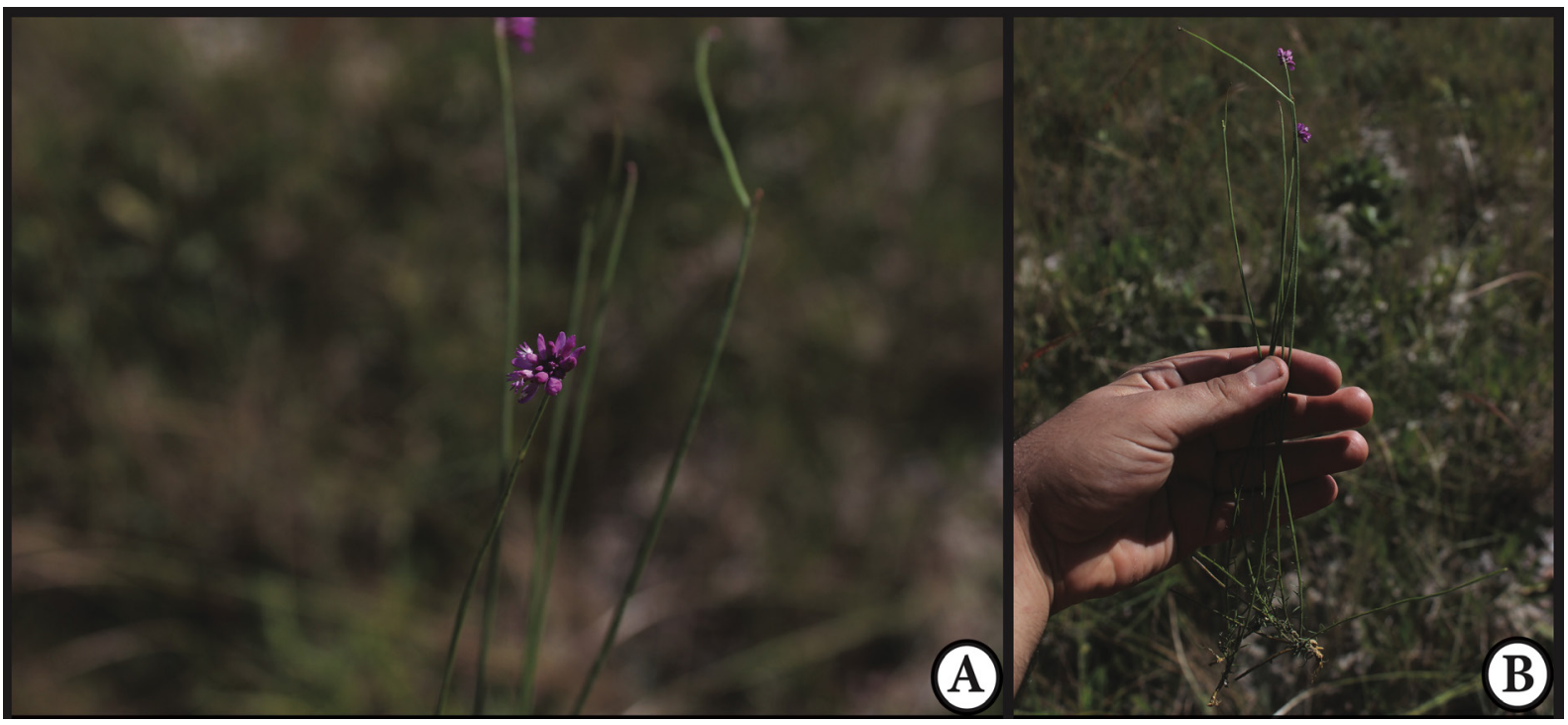

Fig. 5. Polygala tocantinensis J.F.B.Pastore \& Antar sp. nov. A. Inflorescence detail. B. Habit. Photos: G.M. Antar, in situ.

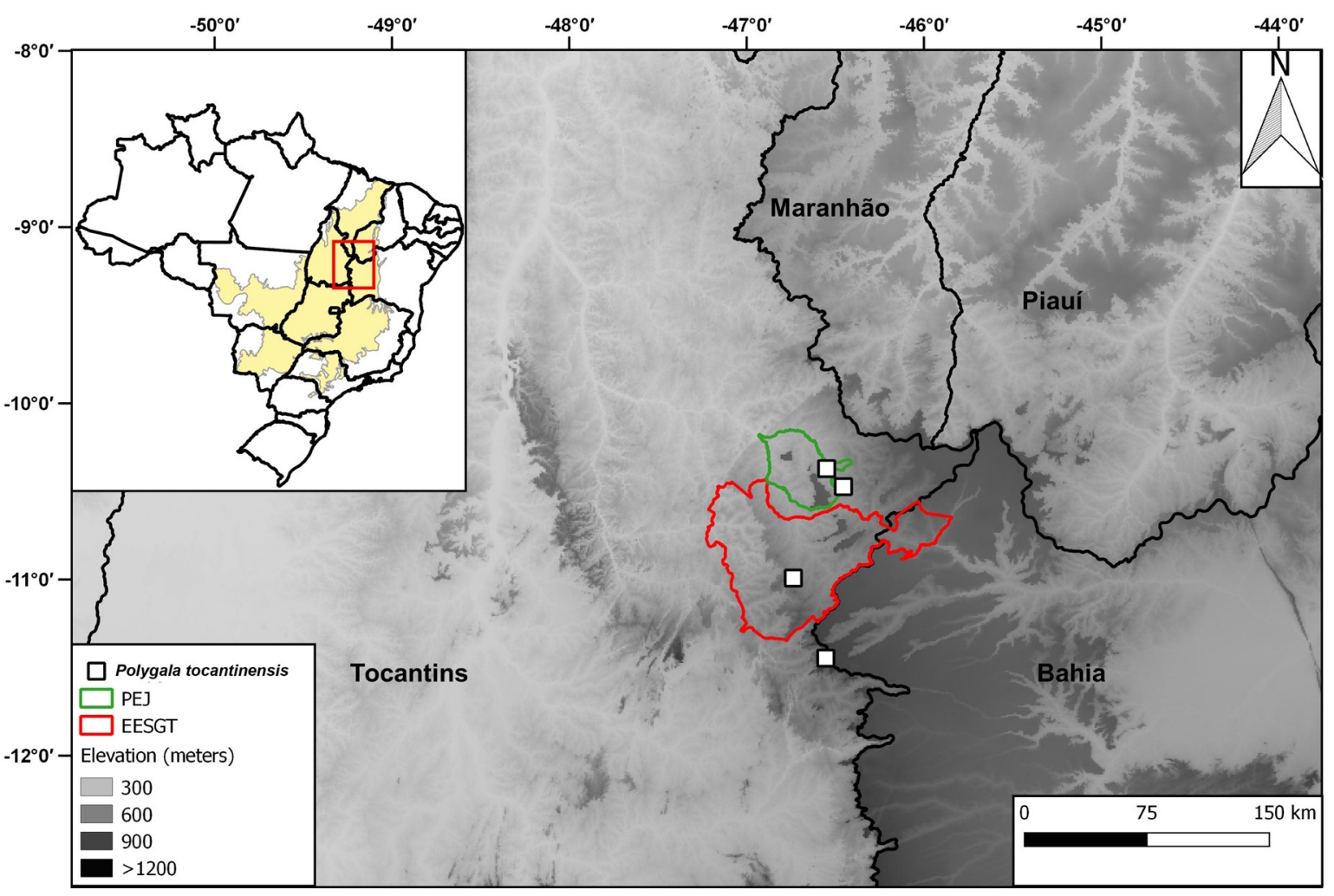

Fig. 6. Geographical distribution of Polygala tocantinensis J.F.B.Pastore \& Antar sp. nov. (squares). PEJ = Parque Estadual do Jalapão, EESGT = Estação Ecológica Serra Geral do Tocantins. The creamcolored portion of the insert map shows the extent of the Cerrado domain in Brazil. 


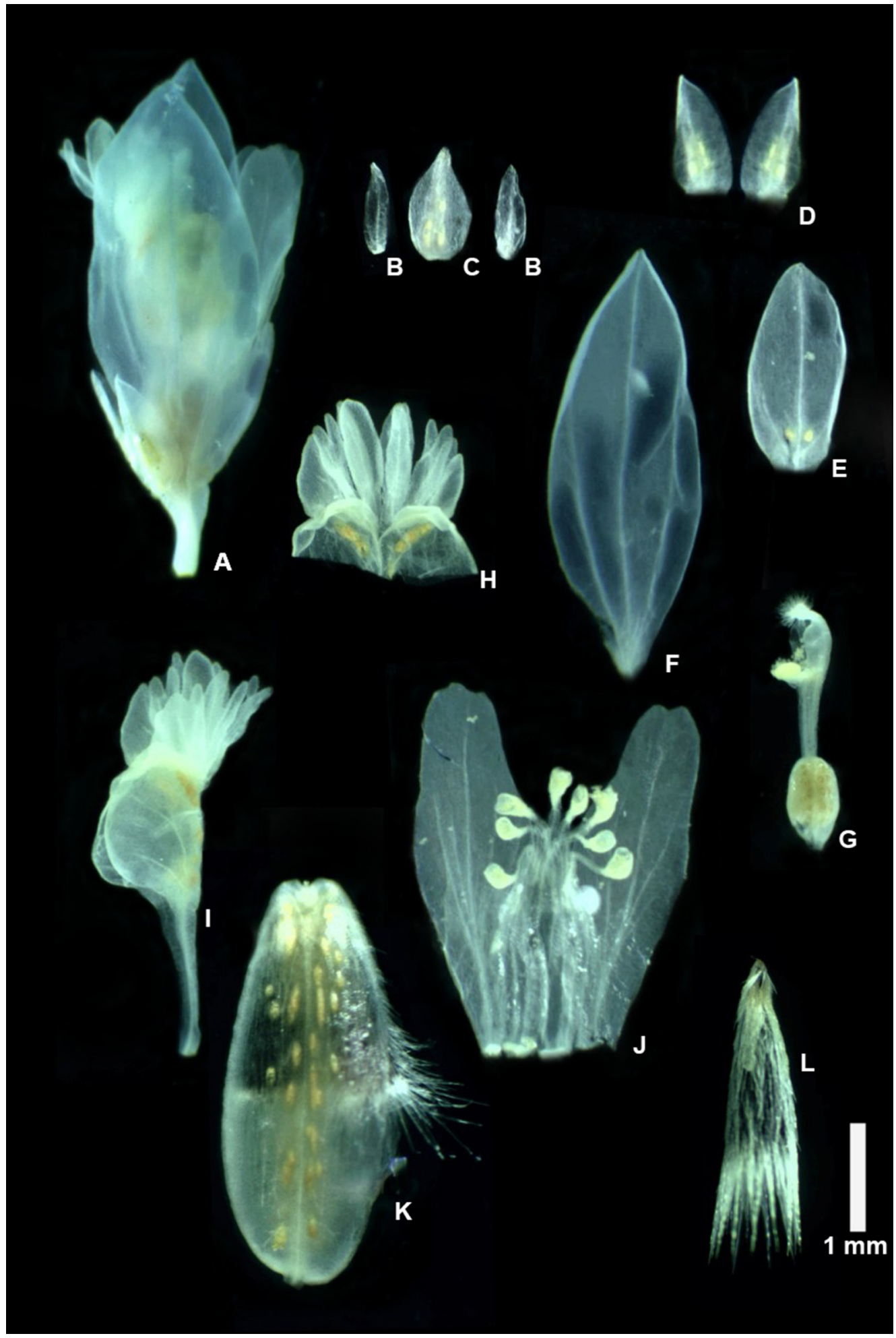

Fig. 7. Polygala trichosperma Jacq. A. Flower. B. Bracteoles. C. Bracts. D. Two upper outer sepals. E. Lower outer sepal. F. One of the two inner sepals (wings). G. Gynoecium. H. Crest. I. Keel. J. Androecium and lateral petals. K. Capsule. L. Seed. All from J.R. Abbott 19728. Photos: J.F.B. Pastore. 


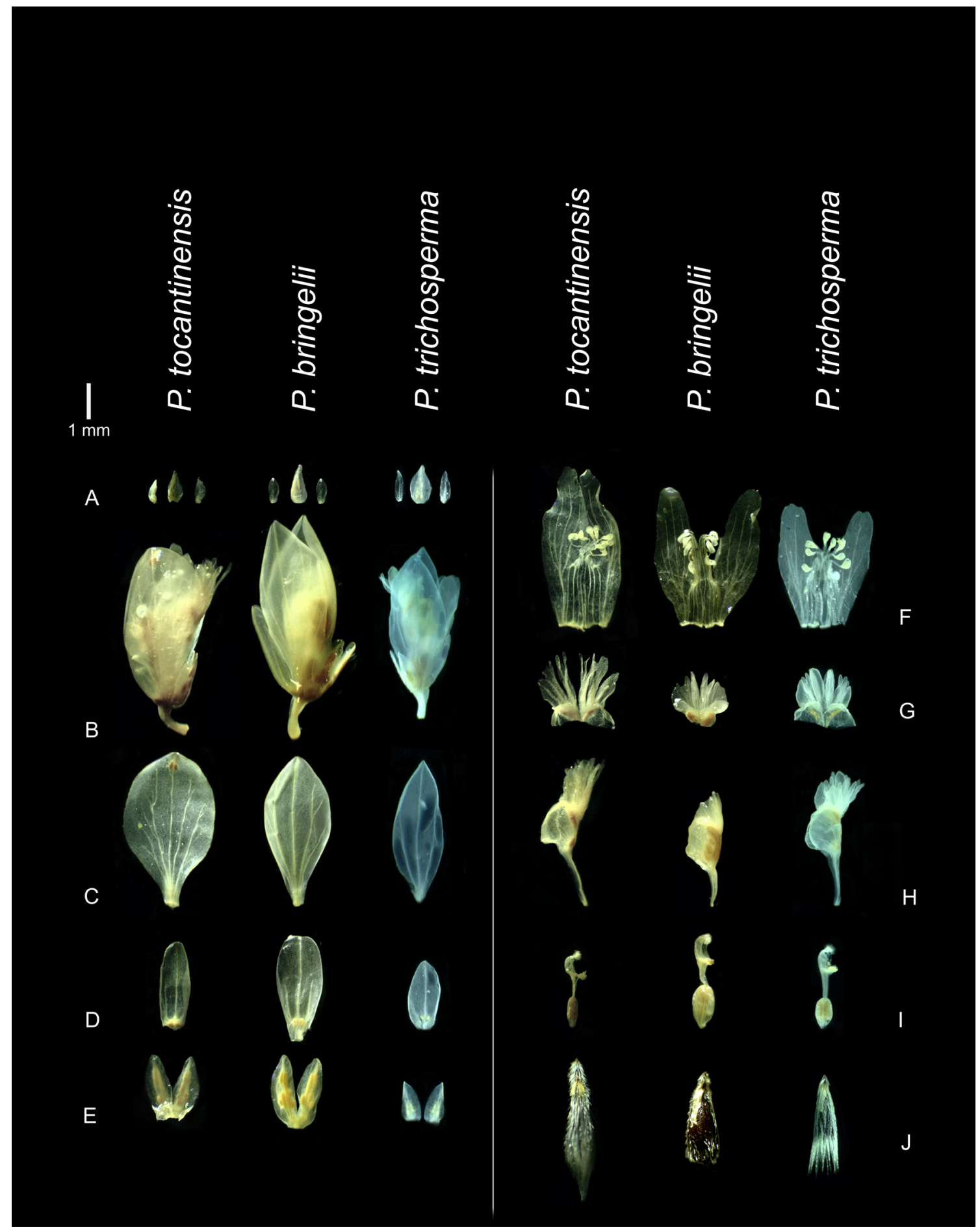

Fig. 8. Comparative plate of floral parts of P. bringelii J.F.B.Pastore \& Antar sp. nov. (G.M. Antar \& L. Nascimento 380), P. tocantinensis J.F.B.Pastore \& Antar sp. nov. (J.M. Silva et al. 6769), and P. trichosperma Jacq. (J.R. Abbott 19728). A. Bracts and bracteoles. B. Flowers. C. Inner sepals (wings). D. Lower outer sepal. E. Two upper outer sepals. F. Androecium and lateral petals. G. Crest. H. Keel. I. Gynoecium. J. Seed. Photos: J.F.B. Pastore. 


\section{Key to Brazilian species of Polygala sect. Timutua ser. Trichospermae Chodat}

1. Aphyllous plants or with scale like leaves (eventually leaves at first nodes are ovate or elliptic).... 2

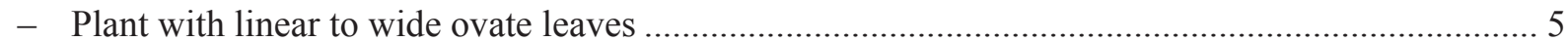



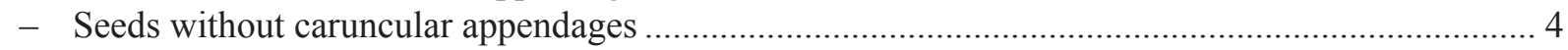

3. Seeds without a ring of trichomes at the base of the seed, tricomes uncinate...... P. apparicioi Brade

- Seeds with a ring of trichomes at the base of the seed, trichomes straight.

P. tocantinensis J.F.B.Pastore \& Antar sp. nov.

4. Plant brownish, freshy, corolla caducous in frutification..........P. saprophytica Chodat ex Grondona

- Plant greenish, not freshy, corolla persistent in frutification..... P. subtilis Kunth

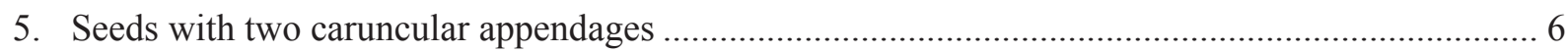

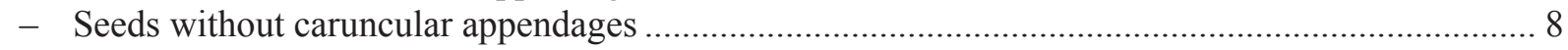

6. With a ring of trichomes at the base of the seed................................................. trichosperma Jacq.

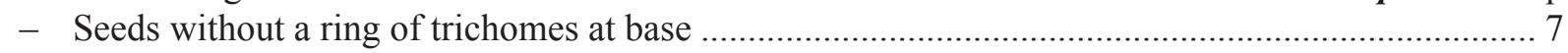

7. Seeds with caruncular appendages ca $1 / 2$ of the seeds, with uncinate trichomes

P. juncea A.St.-Hil. \& Moq.

- Seeds with appendiges reaching not more than $1 / 4$ of the length, trichomes straight

P. bringellii J.F.B.Pastore \& Antar sp. nov.

8. Keel much longer (at least $80 \%$ longer) than the internal sepals (wings); style ca 5 times as long as the ovary; crest of keel wider in the apex (petal-like)

P. adenophora DC.

- Keel shorter or longer (not more than 20\%) than the internal sepal (wings); style shorter or the same length of the ovary, crest of the keel not wider in the apex (not petal-like).

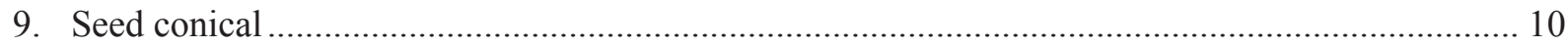

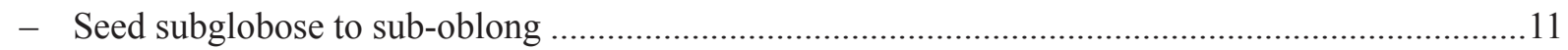

10. Pedicel 1.8-3.5 mm long; corolla caducous on mature fruit

P. longicaulis Kunth

- Pedicel 0.5-0.8 mm long, corolla persistent on mature fruit. P. pseudovariabilis Chodat

11. Seed subglobose, glabrous or with uncinate trichomes.....

P. chapadensis Chodat ex Grondona

- Seeds suboblong, with straight or curved trichomes, never uncinate...P. herbiola A.St.-Hil. \& Moq.

\section{Discussion}

Due to the presence of short racemes, yellowish glands on the floral parts, the erect gynoecium and long pilose seeds, Polygala bringelii sp. nov. and P. tocantinensis sp. nov. are both members of $P$. sect. Timutua ser. Trichospermae. Both species are morphologically most closely related to Polygala trichosperma (Figs 7-8), a widely distributed species found from Mexico to Central Brazil (Bernardi 2000; Aymard et al. 2004).

A similar pattern of Cerrado species with a restricted distribution and morphologically related to widely distributed species has been documented for the recently described Couepia brevistaminea Barb.Silva \& Antar (Barbosa-Silva \& Antar 2020), Euphorbia adenoplicata O.L.M.Silva \& Cordeiro (Silva et al. 2020), and Mimosa carolina M.Morales \& Marc.F.Simon (Morales et al. 2020). Future 
phylogenetic studies may shed light on their putative evolutionary relatedness to the widely distributed taxa. They may also help us to understand the diversification mechanisms in domains (e.g., Cerrado, Llanos) where fire seems to play an important role in lineages establishment (Simon et al. 2009; Simon \& Pennington 2012).

Within the description of Polygala bringelii sp. nov., the number of endemic species of the Jalapão region stands now at 12 (Antar \& Sano 2019). They should be included in future conservation plans for the protected areas of the region. This is also true of Polygala tocantinensis sp. nov., a species of restricted distribution.

\section{Acknowledgements}

We thank Alex Popovkin for the paper review; curators and staff of the visited herbaria and Paulo T. Sano, Ubiratan Chagas, Lucas Nascimento, Marcela Escaramai, Heloisa Antar, Vera Scatena, Rebeca Viana, and Márcio Martins for help during field work. This study was financed in part by the Coordenação de Aperfeiçoamento de Pessoal de Nível Superior - Brasil (CAPES) - Finance Code 001. JFBP is grateful to the Conselho Nacional de Desenvolvimento Científico e Tecnológico (CNPq) for the financial support (grant\# 302452/2017-6). GMA thanks the CAPES, American Society of Plant Taxonomists, and Idea Wild for their financial support.

\section{References}

Antar G.M., Santos M.F. \& Sano P.T. 2018. Rediscovery and taxonomic reassessment of four angiosperms in the savannas of Jalapão, Central Brazil. Edinburgh Journal of Botany 75: 55-71. https://doi.org/10.1017/S0960428617000348

Antar G.M. \& Sano P.T. 2019. Angiosperms of dry grasslands and savannas of Jalapão, the largest conserved Cerrado area in Brazil. Rodriguésia 70: e04002017. https://doi.org/10.1590/2175-7860201970070

Araújo D., Antar G.M. \& Lombardi J.A. 2016. Dioscorea compacta (Dioscoreaceae), a new endangered dwarf species from the Jalapão region, Tocantins, Brazil. Kew Bulletin 71: 27-32. https://doi.org/10.1007/s12225-016-9635-8

Aymard G.A., Berry P.E. \& Eriksen B. 2004. Polygalacaeae. In: Steyermark J.A., Berry P.E., Yatskievych K. \& Holst B.K. (eds) Flora of the Venezuelan Guayana. Vol. 8: 316-347. Missouri Botanical Garden Press, Saint Louis.

Bachman S., Moat J., Hill A.W., de la Torre J. \& Scott B. 2011. Supporting Red List threat assessments with GeoCAT: geospatial conservation assessment tool. ZooKeys 150: 117-126. https://doi.org/10.3897/zookeys.150.2109

Barbosa-Silva R.G. \& Antar G.M. 2020. Description vs deforestation: Couepia brevistaminea (Chrysobalanaceae), a new species on the frontier of agricultural expansion in the Brazilian savanna. Phytotaxa 471 (1): 38-46. https://doi.org/10.11646/phytotaxa.471.1.4

Beentje H. 2012. The Kew Plant Glossary: an illustrated Dictionary of Plant Terms. Royal Botanical Garden, Kew.

Beuchle R., Grecchi R.C., Shimabukuro Y.E., Seliger R., Eva H.D., Sano E. \& Achard F. 2015. Land cover changes in the Brazilian Cerrado and Caatinga biomes from 1990 to 2010 based on a systematic remote sensing sampling approach. Applied Geography 58: 116-127.

Bernardi L.A. 2000. Consideraciones taxonómicas y fitogeográficas acerca de 101 Polygalae Americanas. Cavanillesia Altera 1: 1-455.

BFG - The Brazil Flora Group 2015. Growing knowledge: an overview of seed plant knowledge in Brazil. Rodriguésia 66: 1085-1113. https://doi.org/10.1590/2175-7860201566411 
Blake S.F. 1916. A revision of the genus Polygala in Mexico, Central America, and the West Indies. Contributions from the Gray Herbarium of Harvard University 47: 1-122.

https://doi.org/10.5962/bhl.title.4348

Borges L.M. \& Antar G.M. 2016. Four they are! Broadening the description of Mimosa flabellifolia (Leguminosae Mimosoideae), a rare species from the Brazilian Cerrado. Phytotaxa 243: 155-162. https://doi.org/10.11646/phytotaxa.243.2.5

Chodat R.H. 1893. Monographia polygalacearum. Mémoires de la Société de Physique et d'Histoire Naturelle de Genève. 31: 1-500.

Flora do Brasil 2020. Instituto de Pesquisas Jardim Botânico do Rio de Janeiro. Available from http://floradobrasil.jbrj.gov.br/ [accessed 22 Jan 2021].

Forzza R.C., Baumgratz J.F.A., Bicudo C.E.M., Canhos D.A.L., Carvalho A., Coelho M.A.N., Costa A.F., Costa D.P., Hopkins M.G., Leitman P.M., Lohmann L.G., Lughadha E.N., Maia L.C., Martinelli G., Menezes M., Morim M.P., Peixoto A.L., Pirani J.R., Prado J., Queiroz L.P., Souza S., Souza V.C., Stehmann J.R., Sylvestre L.S., Walter B.M.T. \& Zappi D.C. 2012. New Brazilian floristic list highlights conservation challenges. Bioscience 62: 39-45. https://doi.org/10.1525/bio.2012.62.1.8

Harris J.G. \& Harris M.W. 2001. Plant Identification Terminology: an illustrated Glossary. Second edition. Spring Lake Publishing, Spring Lake.

Hickey L.J. 1973. Classification of the architecture of dicotyledonous leaves. American Journal of Botany 60 (1): 17-33. https://doi.org/10.1002/j.1537-2197.1973.tb10192.x

Klink C.A. \& Machado R.B. 2005. Conservation of Brazilian Cerrado. Conservation Biology 19: 707713.

Marques M.C.M. 1988. Polígalas do Brasil V, seção Polygala (Polygalaceae). Arquivos do Jardim Botânico do Rio de Janeiro 29: 1-114.

Mittermeier R.A., Turner W.R., Larsen F.W., Brooks T.M. \& Gascon C. 2011. Global biodiversity conservation: the critical role of hotspots. In: Zachos E. \& Habel J.C. (eds) Biodiversity Hotspots: 3-22. Springer Publishers, London. https://doi.org/10.1007/978-3-642-20992-5_1

Mori S.A., Berkov A., Gracie C.A. \& Hecklau E.F. 2011. Tropical Plant Collecting-from the Field to the Internet. First edition. TECC Editoria, Florianópolis.

Morales M., Fortunato R.H. \& Simon M.F. 2020. A new species of Mimosa L. ser. Bipinnatae DC. (Leguminosae) from the Cerrado: taxonomic and phylogenetic insights. Plants 9: 934. https://doi.org/10.3390/plants9080934

Moreira A.L.C., Antar G.M., Simão-Bianchini R. \& Cavalcanti T.B. 2017. Contribution to the knowledge of Bonamia (Convolvulaceae) in Brazil: a new species and a new occurrence. Phytotaxa 306: 146-152. https://doi.org/10.11646/phytotaxa.306.2.4

Pastore J.F.B. 2013. Polygala judithea (Polygalaceae), a new species from Chapada dos Veadeiros, Goiás, Brazil. Kew Bulletin 68: 301-304. https://doi.org/10.1007/s12225-013-9440-6

Pastore J.F.B. 2016a. A new endangered species of Polygala (Polygalaceae) from Niquêlandia, Goiás, Brazil. Phytotaxa 288 (1): 96-100. https://doi.org/10.11646/phytotaxa.288.1.11

Pastore J.F.B. 2016b. Polygala minarum (Polygalaceae), a new species endemic to southern Minas Gerais, Brazil. Kew Bulletin 71: 42-47. https://doi.org/10.1007/s12225-016-9658-1

Pastore J.F.B. 2018a. A new species and new combination on Polygala sect. Timutua series Timoutoideae from Brazil. Kew Bulletin 73: 51. https://doi.org/10.1007/s12225-018-9773-2

Pastore J.F.B. 2018b. Polygala veadeiroensis (Polygalaceae), a new species of Polygala endemic to Chapada dos Veadeiros, Goiás, Brazil. Kew Bulletin 73: 37-39.

https://doi.org/10.1007/s12225-018-9759-0 
Pastore J.F.B., Abbott J.R., Neubig K.M., Van Den Berg C., Mota M.C.D.A., Cabral A. \& Whitten W.M. 2019. Phylogeny and biogeography of Polygala (Polygalaceae). Taxon 68: 673-691. https://doi.org/10.1002/tax.12119

QGIS Development Team. 2020. QGIS Geographic Information System. Open Source Geospatial Foundation Project. Available from http://qgis.osgeo.org [accessed 23 May 2020].

Ratter J.A., Ribeiro J.F. \& Bridgewater S. 1997. The Brazilian Cerrado vegetation and threats to its biodiversity. Annals of Botany 80: 223-230. https://doi.org/10.1006/anbo.1997.0469

Schmidt I.B., Figueiredo I.B. \& Scariot A. 2007. Ethnobotany and effects of harvesting on the population ecology of Syngonanthus nitens (Bong.) Ruhland (Eriocaulaceae), a NTFP from Jalapão region, central Brazil. Economic Botany 61: 73-85. https://doi.org/fqv79k

Schmidt I.B., Moura L.C., Ferreira M.C., Eloy L., Sampaio A.B., Dias P.A. \& Berlinck C.N. 2018. Fire management in the Brazilian savanna: First steps and the way forward. Journal of Applied Ecology 55: 2094-2101. https://doi.org/10.1111/1365-2664.13118

Silva J.M.C. \& Bates J.M. 2002. Biogeographic patterns and conservation in the South America Cerrado: a tropical savana hotspot. BioScience 52: 225-233. https://doi.org/fkf9wj

Silva O.L.M., Antar G.M., Riina R. \& Cordeiro I. 2020. Euphorbia adenoplicata, a new species of Euphorbia sect. Crossadenia from Brazil. Systematic Botany 45 (1): 131-136. https://doi.org/10.1600/036364420X15801369352388

Simon M.F., Grether R., Queiroz L.P., Skema C., Pennington R.T. \& Hughes C.E. 2009. Recent assembly of the cerrado, a neotropical plant diversity hotspot, by in situ evolution of adaptations to fire. Proceedings of the National Academy of Sciences of the United States of America 106 (48) : 20359-20364. https://doi.org/10.1073/pnas.0903410106

Simon M.F. \& Pennington T. 2012. Evidence for adaptation to fire regimes in the tropical savannas of the Brazilian Cerrado. International Journal of Plant Sciences 173 (6): 711-723.

Strassburg B.B.N., Brooks T., Feltran-Barbieri R., Iribarrem A., Crouzeilles R., Loyola R., Latawiec A.E., Oliveira Filho F.J.B., Scaramuzza C.A. de M., Scarano F.R., Soares-Filho B. \& Balmford A. 2017. Moment of truth for the Cerrado hotspot. Nature Ecology \& Evolution 1: 0099. https://doi.org/10.1038/s41559-017-0099

Thiers B. 2021. Index Herbariorum: A global directory of public herbaria and associated staff. New York Botanical Garden's Virtual Herbarium. Available from: http://sweetgum.nybg.org/science/ih/ [accessed 7 Mar 2021].

Manuscript received: 26 April 2021

Manuscript accepted: 16 July 2021

Published on: 16 August 2021

Topic editor: Frederik Leliaert

Desk editor: Solene Kowalski

Printed versions of all papers are also deposited in the libraries of the institutes that are members of the EJT consortium: Muséum national d'histoire naturelle, Paris, France; Meise Botanic Garden, Belgium; Royal Museum for Central Africa, Tervuren, Belgium; Royal Belgian Institute of Natural Sciences, Brussels, Belgium; Natural History Museum of Denmark, Copenhagen, Denmark; Naturalis Biodiversity Center, Leiden, the Netherlands; Museo Nacional de Ciencias Naturales-CSIC, Madrid, Spain; Real Jardín Botánico de Madrid CSIC, Spain; Zoological Research Museum Alexander Koenig, Bonn, Germany; National Museum, Prague, Czech Republic. 